\title{
Acute-onset dacryoadenitis following immunisation with mRNA COVID-19 vaccine
}

\author{
Treasa Murphy, ${ }^{1}$ Abdul Raheem Abu Shanab, ${ }^{1}$ Kristopher Kang, ${ }^{2}$ Christopher J Lyons ${ }^{1,3}$
}

'Ophthalmology, British Columbia Children's Hospital, Vancouver, British Columbia, Canada

2Paediatrics, British Columbia Children's Hospital, Vancouver, British Columbia, Canada ${ }^{3}$ Ophthalmology and Visual Sciences, University of British Columbia, Vancouver, British Columbia, Canada

Correspondence to Dr Treasa Murphy; treasa.murphy50@gmail.com

Accepted 22 February 2022

Check for updates

(c) BMJ Publishing Group Limited 2022. No commercial re-use. See rights and permissions. Published by BMJ.

To cite: Murphy T,

Raheem Abu Shanab A,

Kang K, et al. BMJ Case

Rep 2022;15:e248441.

doi:10.1136/bcr-2021-

248441

\section{SUMMARY}

A 14-year-old boy was referred to the ophthalmology department with a 4-day history of rapid-onset right upper lid pain, swelling and erythema starting 9 hours after his first dose of COVID-19 mRNA vaccination (BNT162b2/Comirnaty, Pfizer-BioNTech). On examination, he had significant right upper lid ptosis, oedema and erythema, with associated limitation of right eye abduction and elevation. He was found to have acute dacryoadenitis with orbital inflammatory disease on clinical and laboratory investigations. He was given tapering oral prednisone and had full resolution of symptoms within 2 weeks. This is the first known case of orbital inflammation after COVID-19 mRNA vaccination. Given the temporal association between the patient's vaccination and symptom onset, we believe it is likely that immunisation prompted the onset of disease.

\section{BACKGROUND}

The lacrimal gland is an integral component of the mucosal immune system, which protects the ocular surface. ${ }^{1}$ Acute dacryoadenitis is characterised by rapid enlargement of the lacrimal gland. It is often caused by viral or autoimmune disease. ${ }^{2}$

Ocular manifestations of the novel coronavirus (SARS-CoV-2) include changes consistent with follicular conjunctivitis in up to $32 \%$ of patients, ${ }^{3}$ with reports of anterior segment and posterior segment inflammatory ${ }^{45}$ and vascular changes ${ }^{6}$ and rare cases of orbital inflammation. ${ }^{278}$

Given the recent introduction of COVID-19 mRNA vaccines, data on short-term and long-term side effects are still evolving. Several case reports have noted the development of intraocular immunological and inflammatory events after COVID-19 19 mRNA vaccination, ${ }^{9}$ including cranial nerve palsies, ${ }^{10}{ }^{11}$ uveitis, $^{12}{ }^{13}$ episcleritis, ${ }^{14}$ anterior scleritis, ${ }^{12}$ acute-onset central serous chorioretinopathy ${ }^{15}$ and acute macular neuropathy ${ }^{16}$ within 72 hours of receiving COVID-19 mRNA vaccinations.

To date, orbital inflammatory side effects of COVID-19 mRNA vaccines have not been reported. We present a healthy teenage boy who presented

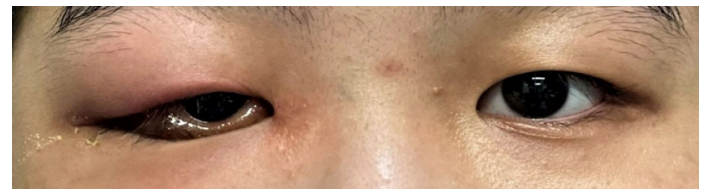

Figure 1 Macroscopic photograph of both eyes. Right upper lid ptosis, erythema and oedema, with associated conjunctival injection and chemosis. with unilateral acute-onset dacryoadenitis, 9 hours after receiving a first dose of COVID-19 mRNA vaccine.

\section{CASE REPORT}

A 14-year-old previously healthy boy, presented with a 4-day history of rapid-onset right upper lid pain, swelling and erythema starting 9 hours after his first dose of COVID-19 mRNA vaccination (BNT162b2/Comirnaty, Pfizer-BioNTech). There was no history of fever or respiratory symptoms. Systemic review was unremarkable. There was no recent travel history or history of COVID-19 infection.

On examination, visual acuities were $6 / 6$ in each eye. The patient had right upper lid S-shaped ptosis, erythema and oedema (figure 1). There was conjunctival chemosis and significant conjunctival injection was noted over the right lateral rectus muscle. The right globe was mildly proptosed with inferomedial globe displacement. Abduction and elevation of the right eye were severely limited with associated diplopia. Anterior segment and dilated fundal examination were normal.

\section{INVESTIGATIONS}

CT scan with intravenous contrast demonstrated an elliptical rim-enhancing collection at the right lacrimal gland that was enlarged compared with the left side. There was associated thickening of the lateral rectus and stranding of the overlying subcutaneous soft tissue anteriorly. There was no associated sinus disease (figure 2).

Laboratory testing showed white blood cell count $8.2 \times 10^{9} / \mathrm{L}$, and $\mathrm{C}$ reactive protein $10 \mathrm{mg} / \mathrm{L}$. Electrolytes, creatinine, hepatic transaminases, gamma glutamyltransferase, bilirubin, uric acid, lactate dehydrogenase and thyroid stimulating hormone were normal. Blood cultures and conjunctival swabs were negative. Epstein-Barr virus IgG and IgM antibody titres were negative.

Based on clinical and laboratory investigations, this patient was diagnosed with acute dacryoadenitis with associated orbital inflammatory disease.

\section{TREATMENT}

The patient was admitted to hospital and started on empiric treatment with intravenous ceftriaxone and metronidazole two times daily. However, after noting no improvement after 1 day, he was started on oral prednisone $60 \mathrm{mg}$ daily.

\section{OUTCOME AND FOLLOW-UP}

After 2 days, the pain had resolved, and the lid and conjunctival inflammation were improved. Eye 


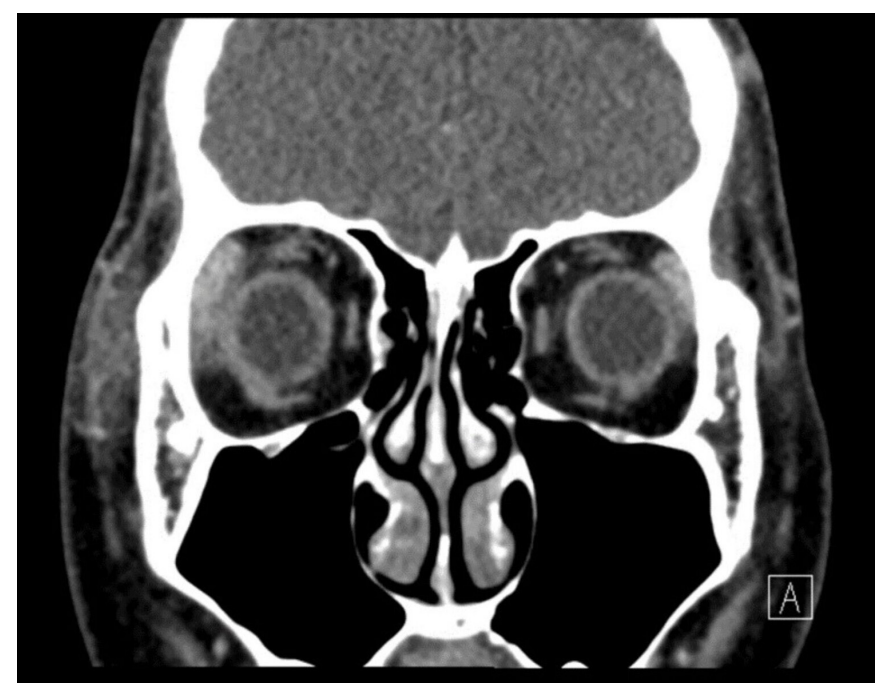

Figure 2 Coronal CT scan. Enlargement of the right lacrimal gland and lateral rectus with associated preseptal and eyelid oedema.

movements were now full. Intravenous antibiotics were discontinued. The prednisone dose was tapered to zero over 2 weeks. The patient subsequently declined his second COVID-19 immunisation.

\section{DISCUSSION}

We report acute dacryoadenitis with associated ophthalmoplegia in a 14-year-old boy occurring 9 hours after COVID-19 mRNA vaccination. To our knowledge, this is the first known case of orbital inflammation after COVID-19 mRNA vaccination. Given the temporal association between the patient's vaccination and symptom onset, we believe it is likely that immunisation prompted the onset of disease. However, as noted in other case reports, it is unknown whether this is a coincidental or causal relationship.

Four cases of orbital inflammation secondary to COVID-19 infection have been reported. ${ }^{278}$ All patients were sero-positive for Sars-CoV-2 infection and were otherwise asymptomatic. One of these patients had dacryoadenitis, ${ }^{2}$ one had dacryoadenitis with associated orbital myositis ${ }^{8}$ and two had non-specific intraconal orbital inflammatory changes with associated sinusitis. ${ }^{7}$

$\mathrm{Ng}$ et al recently comprehensively reviewed the ocular side effects of COVID-19 vaccination. ${ }^{14}$ The most prevalent complications of mRNA vaccination were Bell's/facial nerve palsy $(n=30)$, followed by corneal graft rejection $(n=6)$, panuveitis $(n=2)$, acute abducens nerve palsy $(n=1)$, reactivation of VogtKoyanagi-Harada disease $(n=2)$, acute central serous retinopathy $(n=1)$, activation of Graves' disease $(n=2)$, acute macular neuroretinopathy $(n=1)$ and central retinal vein occlusion $(n=2)$.

Furthermore, Lin et $a l^{9}$ recently described adverse ocular outcomes of acute abducens nerve palsy, uveitis, Vogt-KoyanagiHarada disease activation, anterior ischaemic optic neuropathy and acute corneal graft rejection after Pfizer-BioNTech vaccination. Testi et $a l^{12}$ reported 70 patients who presented with ocular inflammatory events within 14 days of COVID-19 vaccination, including anterior and posterior uveitis, and scleritis. Over half of this cohort had a previous ocular inflammatory event.

The contribution of the lacrimal gland to the ocular mucosal immune system is well described; committed B and T cells in the gland produce surface $\operatorname{IgA}$ and $\operatorname{IgG}$, respectively. ${ }^{1}$ IgA plays a central role in the body's local mucosal immune response. A

\section{Patient's perspective}

Nine hours after my first dose of vaccine, I noticed that my right eye was really swollen and sore. I didn't really get a fright. We went to the hospital, and I just trusted the doctors and nurses to make things better. I'm doing fine now. I'm glad that other people get to hear about my case. My advice to anyone in a similar situation would be to stay calm. What happened to me is really rare, I'm not going to frighten my friends about the vaccine. I do feel a bit worried about getting my second dose and I hope this doesn't happen again.

\section{Learning points}

- This is the first described case of orbital inflammation after COVID-19 mRNA vaccination.

- This patient presented with classical dacryoadenitis clinical findings.

- Treatment with a tapering dose of oral prednisone led to full resolution of this patient's inflammation.

- Acute dacryoadenitis and orbital inflammatory syndrome due to local immunological response may potentially occur after COVID-19 mRNA immunisation, although a causal relationship cannot be confirmed at this stage.

recent paper by Jalkanen et $a l^{17}$ noted a significant increase of serum anti-SARS-CoV-2 (anti-S1) IgG and moderate increase of anti-S1 IgA in BNT162b2/Comirnaty vaccine recipients 3 weeks after immunisation. Furthermore, recent research by Muyldermans et $a l^{18}$ showed the presence of SARS-CoV-2 IgA and IgG antibodies in the tear film of convalescent COVID-19 infected individuals compared with control patients. We speculate that this patient developed an acute-onset dacryoadenitis and orbital inflammatory syndrome secondary to lacrimal gland immunological response to the COVID-19 mRNA vaccination, although a causal relationship cannot be confirmed at this stage.

Contributors TM drafted the manuscript with significant input and edits from ARAS, KK and CL. CL and KK encouraged literature review and manuscript submission.

Funding The authors have not declared a specific grant for this research from any funding agency in the public, commercial or not-for-profit sectors.

Competing interests None declared.

Patient consent for publication Consent obtained from parent(s)/guardian(s) Provenance and peer review Not commissioned; externally peer reviewed.

Case reports provide a valuable learning resource for the scientific community and can indicate areas of interest for future research. They should not be used in isolation to guide treatment choices or public health policy.

\section{REFERENCES}

1 Saitoh-Inagawa W, Hiroi T, Yanagita M, et al. Unique characteristics of lacrimal glands as a part of mucosal immune network: high frequency of IgA-committed B-1 cells and NK1.1+ alphabeta T cells. Invest Ophthalmo/ Vis Sci 2000;41:138-44.

2 Martínez Díaz M, Copete Piqueras S, Blanco Marchite C, et al. Acute dacryoadenitis in a patient with SARS-CoV-2 infection. Orbit 2021:1-4.

3 Peng M, Dai J, Sugali CK, et al. The role of the ocular tissue in SARS-CoV-2 transmission. Clin Ophthalmol 2020;14:3017-24.

4 Otaif W, Al Somali Al, Al Habash A. Episcleritis as a possible presenting sign of the novel coronavirus disease: a case report. Am J Ophthalmol Case Rep 2020;20:100917 
5 Mazzotta C, Giancipoli E. Anterior acute uveitis report in a SARS-CoV-2 patient managed with adjunctive topical antiseptic prophylaxis preventing 2019-nCoV spread through the ocular surface route. Int Med Case Rep J 2020;13:513-20.

6 Marinho PM, Marcos AAA, Romano AC, et al. Retinal findings in patients with COVID-19. Lancet 2020;395:1610.

7 Turbin RE, Wawrzusin PJ, Sakla NM, et al. Orbital cellulitis, sinusitis and intracranial abnormalities in two adolescents with COVID-19. Orbit 2020;39:305-10.

8 Eleiwa T, Abdelrahman SN, ElSheikh RH, et al. Orbital inflammatory disease associated with COVID-19 infection. J Aapos 2021;25:232-4.

9 Lin TPH, Ko C-N, Zheng K, et al. COVID-19: update on its ocular involvements, and complications from its treatments and vaccinations. Asia Pac J Ophthalmol 2021;10:521-9.

10 Ozonoff A, Nanishi E, Levy O. Bell's palsy and SARS-CoV-2 vaccines. Lancet Infect Dis 2021;21:450-2.

11 Shemer A, Pras E, Einan-Lifshitz A, et al. Association of COVID-19 vaccination and facial nerve palsy: a case-control study. JAMA Otolaryngol Head Neck Surg 2021;147:739-43.
12 Testi I, Brandão-de-Resende C, Agrawal R, et al. Ocular inflammatory events following COVID-19 vaccination: a multinational case series. J Ophthalmic Inflamm Infect 2022;12:4.

13 ElSheikh RH, Haseeb A, Eleiwa TK, et al. Acute uveitis following COVID-19 vaccination. Ocul Immunol Inflamm 2021;29:1207-9.

$14 \mathrm{Ng} \mathrm{XL}$, Betzler BK, Ng S, et al. The eye of the storm: COVID-19 vaccination and the eye. Ophthalmol Ther 2022;11:81-100.

15 Fowler N, Mendez Martinez NR, Pallares BV, et al. Acute-onset central serous retinopathy after immunization with COVID-19 mRNA vaccine. Am J Ophthalmol Case Rep 2021;23:101136.

16 Bøhler AD, Strøm ME, Sandvig KU, et al. Acute macular neuroretinopathy following COVID-19 vaccination. Eye 2022;36:644-5.

17 Jalkanen P, Kolehmainen P, Häkkinen HK, et al. COVID-19 mRNA vaccine induced antibody responses against three SARS-CoV-2 variants. Nat Commun 2021;12:3991.

18 Muyldermans A, Bjerke M, Demuyser T, et al. SARS-CoV-2 RNA and antibodies in tear fluid. BMJ Open Ophthalmol 2021;6:e000733.

Copyright 2022 BMJ Publishing Group. All rights reserved. For permission to reuse any of this content visit https://www.bmj.com/company/products-services/rights-and-licensing/permissions/

BMJ Case Report Fellows may re-use this article for personal use and teaching without any further permission.

Become a Fellow of BMJ Case Reports today and you can:

- Submit as many cases as you like

- Enjoy fast sympathetic peer review and rapid publication of accepted articles

- Access all the published articles

- Re-use any of the published material for personal use and teaching without further permission

Customer Service

If you have any further queries about your subscription, please contact our customer services team on +44 (0) 2071111105 or via email at support@bmj.com. Visit casereports.bmj.com for more articles like this and to become a Fellow 